Pesq. Vet. Bras. 36(8):737-742, agosto 2016

DOI: $10.1590 / \mathrm{S} 0100-736 \mathrm{X} 2016000800010$

\title{
Cardiac markers in five different breeds of rabbits (Oryctolagus cuniculus Linnaeus, 1758) used for cardiovascular research ${ }^{1}$
}

\author{
Felipp S. Ferreira ${ }^{2 *}$, Flávia L. Barretto ${ }^{3}$, Arianne Fabres ${ }^{4}$, Leonardo S. Silveira ${ }^{5}$ \\ and Claudio B. Carvalho ${ }^{6}$
}

\begin{abstract}
Ferreira F.S., Barretto F.L., Fabres A., Silveira L.S. \& Carvalho C.B. 2016. Cardiac markers in five different breeds of rabbits (Oryctolagus cuniculus Linnaeus, 1758) used for cardiovascular research. Pesquisa Veterinária Brasileira 36(8):737-742. Instituto Qualittas de Pós-Graduação, Rua Padre Leonel França 641, Jardim Leonor, Campinas, SP 13041-190, Brazil. E-mail: felipp.sf@gmail.com

Cardiac biomarkers for clinical and experimental heart diseases have previously been evaluated in rabbits. However, several laboratory assays performed and reported with inconsistent results. This study aimed to assess the effects of breed on serum ANP, CRP, and ACE and establish reference interval (RI) for these biomarkers in a large population of healthy rabbits. Ninety-seven adult rabbits from five breeds were included in this study. Assays were performed using specific ELISA commercial kits. The results were statistically analyzed using ANOVA, Tukey test $(\mathrm{p}<0.05)$, arithmetic mean, RI of mean, and standard deviation. A significant effect of breed was shown, indicating different RI between breeds for each biomarker. In conclusion, this study demonstrated that breed is an important physiological variable influencing the normal values of cardiac markers in healthy rabbits.

INDEX TERMS: Angiotensin-converting enzyme, atrial natriuretic peptide, breed, C-reactive protein.
\end{abstract}

RESUMO.- [Marcadores cardíacos em cinco diferentes raças de coelhos (Oryctolagus cuniculus Linnaeus, 1758) utilizados para pesquisa cardiovascular.] Biomarcadores cardíacos têm sido avaliados em coelhos para avaliação clínica e experimental das doenças cardíacas. Entretanto diferentes testes laboratoriais têm sido utilizados e relatados, sem uma confluência de resultados. Os objetivos deste estudo foram verificar os efeitos de diferentes raças de coelhos sobre as concentrações séricas de ANP, CRP e

\footnotetext{
${ }^{1}$ Received on August 2, 2015.

Accepted for publication on April 13, 2016.

${ }^{2}$ Instituto Qualittas de Pós-Graduação, Rua Padre Leonel França 641, Jardim Leonor, Campinas, SP, 13041-190, Brazil. *Corresponding author: felipp.sf@gmail.com

${ }^{3}$ Médica Veterinária autônoma, Rua Fontes Castelo 11, Alto da Boa Vista, Rio de Janeiro, RJ 20531-150, Brazil.

${ }^{4}$ Departamento de Imuno/hormônio, Laboratório de Pesquisas Clínicas Plínio Bacelar, Rua José do Patrocínio 99, Centro, Campos dos Goytacazes, RJ 28010-385, Brazil.

${ }^{5}$ Laboratório de Morfologia e Patologia Animal (LMPA), Universidade Estadual do Norte Fluminense Darcy Ribeiro (UENF), Av. Alberto Lamego 2000, Parque Califórnia, Campos dos Goytacazes, RJ 28013-602, Brazil.

${ }^{6}$ Laboratório de Clínica e Cirurgia Animal (LCCA), UENF, Av. Alberto Lamego 2000, Parque Califórnia, Campos dos Goytacazes, RJ 28013-602, Brazil .
}

ACE, além de estabelecer intervalor de referência para estes biomarcadores em uma população de coelhos saudáveis. Foram utilizados noventa e sete coelhos de cinco diferentes raças. Os exames foram realizados pela metodologia de ELISA, por meio de kits comerciais específicos. Os resultados foram analisados estatisticamente os testes de ANOVA e Tukey $(\mathrm{p}<0,05)$, média aritmética, intervalo de referência da média e desvio padrão. Um efeito significativo da raça foi observado sobre as variáveis estudadas, indicando diferentes intervalos de referência entre as raças para cada biomarcador. Em conclusão, este estudo demonstrou que a raça é uma variável fisiológica importante que influencia os valores normais destes biomarcadores em coelhos saudáveis.

TERMOS DE INDEXAÇÃO: Enzima conversora de angiotensina, peptídeo natriurético atrial, proteína $\mathrm{C}$ reativa.

\section{INTRODUCTION}

Rabbits are widely used as laboratory animals for biomedical and cardiovascular research involving biomarkers of disease (Campbell et al. 1978, Yu et al. 1979, Barret et al. 2002, Chorro et al. 2009, Dontas et al. 2011, Özkan et al. 2012). Similarity of cardiac physiology (with humans), docility, easy handling, and adequate physical bearing of rab- 
bits facilitates a series of maneuvers (Flecknell 1993, Fonseca et al. 1996, Petronianu 1996, Pogwizd \& Bers 2008).

However, rabbits exhibit an exceptionally high phenotypic diversity; more than 200 breeds are recognized worldwide. These rabbit breeds vary extensively in weight, body conformation, fur type, coat color, ear length, litter size, growth rate, and behavior. This diversity is utilized for a wide variety of laboratory studies (Carneiro et al. 2011). In a few cases, however, this variability leads to differences in the normal values of important physiological parameters, such as hematologic and biochemical parameters (Casey et al. 1934, Moesgaard et al. 2007, Özkan et al. 2012).

Ishioka et al. (2007), in a series of studies on dogs, investigated the influence of breed and other factors (age, gender, and body condition score) on physiological variables, especially, plasma leptin concentration. In another study, Höllmer et al. (2013) investigated the effects of breed variability on left atrial volume and phasic function in clinically healthy dogs. In a recently published paper, Misbach et al. (2013) investigated the effects of breed variability (including age, gender, and body) on basal plasma concentrations of the cardiac marker, N-terminal pro-B-type natriuretic peptide (NT-proBNP), in clinically healthy adult dogs. In the above study, the authors observed marked differences in plasma levels of NT-proBNP in seven different breeds of dogs. They concluded that breed-specific reference ranges might, therefore, be necessary for optimal clinical use of natriuretic peptides, such as cardiac biomarkers.

Similarly, some important physiological parameters lack reference values in rabbits too, particularly, cardiac markers. This represents a major problem for researchers who need to design their own reference values (Özkan et al. 2012).Considering the frequent use of rabbits in cardiovascular research and extrapolation of data obtained from rabbits to humans, it is important to understand the effects of breed variations on physiological parameters in healthy laboratory animals and the interaction between them for the correct interpretation and implementation of results.

The objectives of this study were as follows: (1) to establish RI for serum concentration of C-reactive protein (CRP), atrial natriuretic peptide (ANP), and angiotensin-converting enzyme (ACE) in a population of healthy rabbits of different breeds, based on the recommendations of the Clinical Laboratory and Standards Institute guidelines (CLSI, 2008); and (2) to assess the effects of breed on these biomarkers.

\section{MATERIALS AND METHODS}

Ethics statement. The study protocol was reviewed and approved by the Ethics Committee for Animal Use of the Darcy Ribeiro North Fluminense State University, CEUA no. 111/2010, Campos dos Goytacazes-RJ, Brazil.

Study design. For this study, 97 adult rabbits (Oryctolagus cuniculus, Linnaeus, 1758) of five different breeds (Fig.1) were utilized. They were divided into five groups, according to the breeds (Table 1).

Animal houses. All animals were supplied by the same hatchery (Coelhos Lagoa Funda ${ }^{\circledR}$, Lagoa Funda, Marataízes-ES, Brazil) and were created and handled the same way. The animals were housed in single rabbit cages at a comfortable temperature of $24 \pm 2{ }^{\circ} \mathrm{C}$. The rabbits were fed with a commercially-available, ad libitum pelleted rabbit food and drinking water. The animals were also cleaned and sunbathed regularly.

Inclusion and exclusion criteria. Inclusion criteria for study animals were normal medical history, physical examination, clinicopathological assessment and electrocardiogram with no evidence of congenital or acquired heart disease. Clinicopathological assessment included complete blood count and biochemistry profile. Exclusion criteria included rabbits less than six months and over eight months old, those with heart murmurs, concurrent diseases, external lesions, electrocardiographic, or hematological
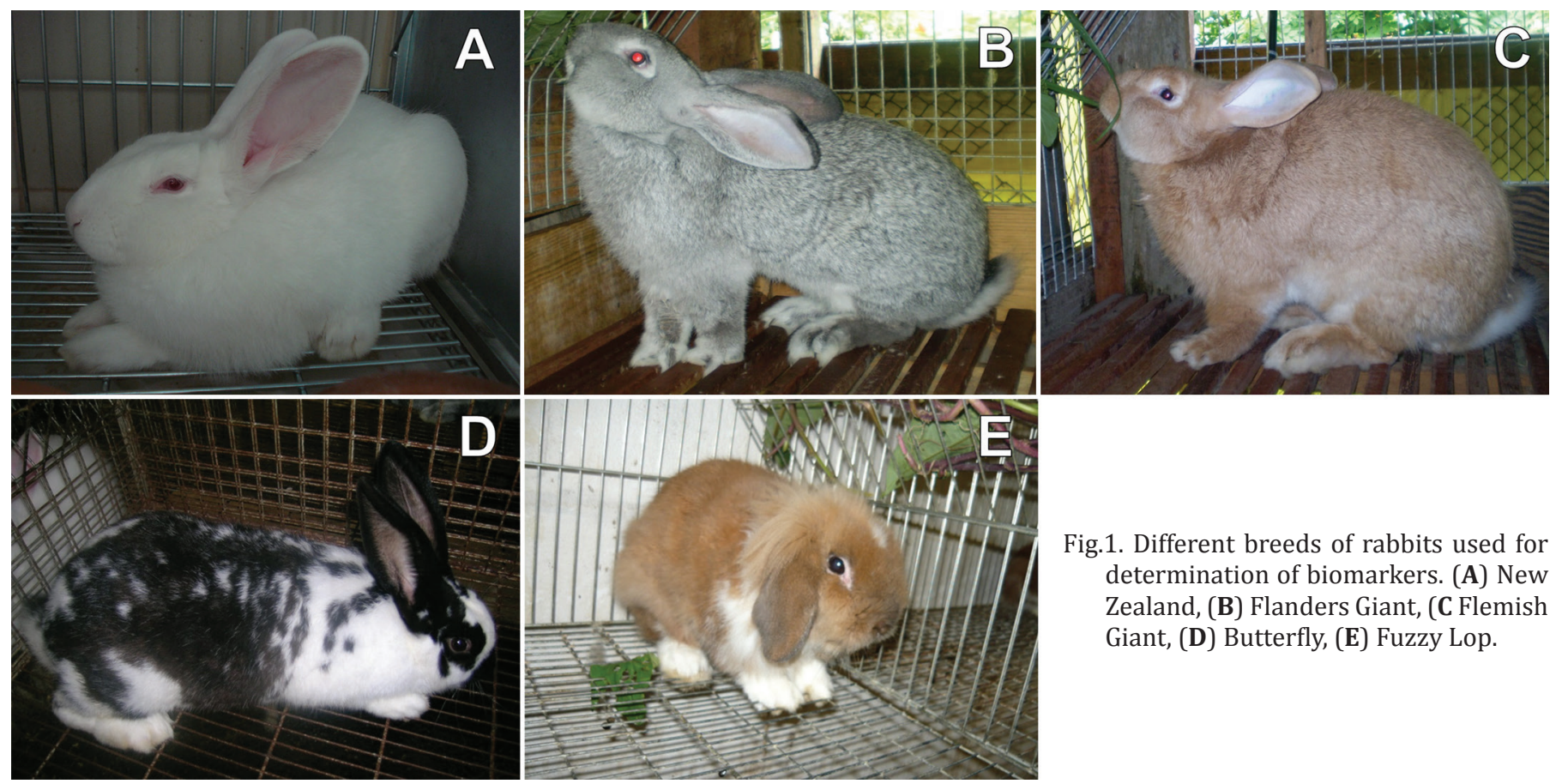

Fig.1. Different breeds of rabbits used for determination of biomarkers. (A) New Zealand, (B) Flanders Giant, (C Flemish Giant, (D) Butterfly, (E) Fuzzy Lop. 
changes and those receiving or having previously received any type of medication.

Electrocardiography was compared to previously published data (Szabuniewicz et al. 1971, Pairaut 2009, Lord et al. 2010). All rabbits included in the study were clinically healthy (based on physical examination) with no evidence of cardiac murmurs.

Sampling. For analysis of cardiac markers, CRP, ANP, and ACE, a minimum volume $(3 \mathrm{ml})$ of venous blood per animal was extracted. All samples were collected on the same day and divided into two equal parts ( $1.5 \mathrm{ml}$ each) for processing in duplicate; this was done to minimize the effects of external, individual, or analytical variations.

For blood collection, the animals were physically restrained in a dorsal recumbent position on a procedure table. A cylindrical support was attached to the cervical dorsal region of animal, exposing the cervical area ventrally. Trichotomy of the ventrolateral region of the neck and asepsis with alcohol 70\% was performed. Blood was obtained from the jugular vein using a sterile needle $(25 \times 7 \mathrm{~mm})$ and syringe $(5 \mathrm{ml})$. The samples were collected in sterile tubes (without anticoagulant) and centrifuged at $1000 \mathrm{~g}$ for $20 \mathrm{~min}$ (in accordance with the protocol provided by the manufacturer). The obtained supernatant was stored for $24 \mathrm{~h}$ in microtubes at $-20^{\circ} \mathrm{C}$. Subsequently, the supernatant was assayed at the Laboratory of Chemistry and Function of Proteins and Peptides, Darcy Ribeiro North Fluminense State University, Campos dos Goytacazes-RJ, Brazil.

Cardiac biomarkers Assay. Cardiac biomarkers were determined by commercially-available specific ELISA kits (Kamiya Biomedical $^{\circledR}, 12779$ Gateway Drive, Seattle, WA 98168, USA) at 450nm on an ELISA device (TP-Reader ${ }^{\circledR}$, RL New Produtos e Equipamentos Laboratoriais, Rio de Janeiro-RJ, Brazil). The protocol provided by the manufacturer was observed. ACE Cat\# KT-51711, ANP Cat\# KT-51718, and hs-CRP Cat\# KT-097 from the same origin and lot, with similar standard curves were used. This was done to minimize the potential influence of analytical factors on results.

Final concentration was determined from the standard curve for each biomarker provided with the kit. The concentrations of

Table 1. Group, breed and gender of 97 healthy rabbits

\begin{tabular}{lcccc}
\hline $\begin{array}{l}\text { Groups/ } \\
\text { characteristics }\end{array}$ & Breed & N & Male/Female & Weight (kg) \\
\hline Group 1 & New Zealand & 24 & $13 / 11$ & $2,4 \pm 0,2$ \\
Group 2 & Flanders Giant & 18 & $10 / 08$ & $7,2 \pm 0,3$ \\
Group 3 & Flemish Giant & 19 & $06 / 13$ & $6,9 \pm 0,2$ \\
Group 4 & Butterfly & 16 & $08 / 08$ & $2,8 \pm 0,2$ \\
Group 5 & Fuzzi Lop & 20 & $11 / 09$ & $1,5 \pm 0,1$ \\
Total & 5 breeds & 97 & $48 / 49$ & $-\mathrm{X}^{-}$
\end{tabular}

the standard curve for ACE, ANP, and hs-CRP were $0-25.0 \mathrm{ng} / \mathrm{ml}$, $0-1000 \mathrm{pg} / \mathrm{ml}$, and $0-200 \mathrm{ng} / \mathrm{ml}$, respectively.

Statistics. For statistical analysis, a value of $\mathrm{p}<0.05$ was considered significant. Lilliefors test data was used for calculating normality and was presented as a normal distribution. The effects of breed, sex, and body weight on serum ANP, ACE, and CRP concentration were tested using ANOVA with post-hoc Tukey test, with the aid of a statistical software package (GraphPad Software $^{\circledR}$, SAS and GENES). Reference intervals for this study were defined as central $95 \%$ intervals bounded by the 2.5 th and 97.5 th percentiles.

\section{RESULTS}

Validation of immunoassay. The validity of the kits used was checked in two ways: using coefficient of variation (CV) and recovery rates supplied by the manufacturer. These represented an intra-assay $\mathrm{CV}$ of $<10 \%$, inter-assay $\mathrm{CV}$ of $<10 \%$ and a recovery of $>85 \%$ for CRP. Additionally, the rates for all markers under study were also verified in our own laboratory. Intra-assay and inter-assay precision was evaluated as described in the literature (Oyama \& Solter 2004). Intra-assay was evaluated by running assaying samples three times in the same run. Inter-assay, on the other hand, was evaluated by running the assay samples once daily for three consecutive days.

Precision was calculated as the coefficient of variation $[\mathrm{CV} \%=$ (standard deviation/average $) \times 100 \%]$. The interand intra-assay $\mathrm{CV}$ were $7.47 \%$ and $4.50 \%$, respectively, for ACE; $5.33 \%$ and $2.96 \%$ respectively, for ANP; and $6.36 \%$ and $6.27 \%$ respectively, for CRP. Recovery of cardiac markers was calculated using concentration values from the literature (Ecker \& CiChna-Markl 2012) and presented as mean \pm SD (recovery for ANP $=103.34 \pm 14.70 \%$, ACE $=105.07 \pm 20.64 \%$, and CRP $=117.56 \pm 17.69 \%)$. Reference intervals, arithmetic means, and standard deviation of cardiac markers (CRP, ANP, and ACE), as well as statistical comparisons between different breed groups, are presented in Table 2.

Cardiac biomarkers. Through use of the Lilliefors test, it was possible to demonstrate a normal distribution of data obtained for the biomarkers ANP, CRP, and ACE with a $\mathrm{p}$ value of $<0.001$.

As observed in Table 2, comparisons between groups of breeds revealed a high statistical difference for serum concentration of CRP $(\mathrm{p}<0.0001)$, ANP $(\mathrm{p}<0.0001)$, and ACE $(\mathrm{p}<0.0001)$. Intragroup analysis, however, did not show

Table 2. Reference intervals, mean and standard deviation of cardiac markers CRP, ANP and ACE in five different breeds of rabbits

\begin{tabular}{|c|c|c|c|c|c|c|c|c|c|}
\hline \multirow[b]{2}{*}{$\begin{array}{l}\mathrm{ACE} \\
(\mathrm{ng} / \mathrm{ml})\end{array}$} & \multicolumn{2}{|c|}{ New Zealand $(\mathrm{N}=24)$} & Flanders Giant $(\mathrm{N}=18)$ & \multicolumn{2}{|c|}{ Flemish Giant $(\mathrm{N}=19)$} & \multicolumn{2}{|c|}{ Butterfly $(\mathrm{N}=16)$} & \multicolumn{2}{|c|}{ Fuzzy Lop $(\mathrm{N}=20)$} \\
\hline & $8,93 \pm 0,43^{a}$ & $8,037-9,826$ & $6,07 \pm 0,33^{\mathrm{b}} \quad 5,38-6,76$ & $5,47 \pm 0,37^{\mathrm{b}}$ & $4,70-6,24$ & $7,11 \pm 0,31^{b}$ & $6,43-7,79$ & $6,46 \pm 0,33^{b}$ & $5,70-7,21$ \\
\hline Male & \multicolumn{2}{|c|}{$8,86 \pm 2,41$} & $6,14 \pm 1,63$ & \multicolumn{2}{|c|}{$6,16 \pm 1,36$} & \multicolumn{2}{|c|}{$7,09 \pm 0,80$} & \multicolumn{2}{|c|}{$6,42 \pm 0,54$} \\
\hline Female & \multicolumn{2}{|c|}{$9,22 \pm 1,92$} & $5,97 \pm 0,83$ & \multicolumn{2}{|c|}{$5,26 \pm 1,53$} & \multicolumn{2}{|c|}{$7,12 \pm 1,18$} & \multicolumn{2}{|c|}{$6,51 \pm 0,96$} \\
\hline $\begin{array}{l}\text { ANP } \\
(\mathrm{pg} / \mathrm{ml})\end{array}$ & \multicolumn{2}{|c|}{$309,55 \pm 13,19^{\text {a }} 281$} & $281,42 \pm 14^{\text {ab }} 250,6-312,2$ & \multicolumn{2}{|c|}{$198,12 \pm 15,11^{\mathrm{b}} 164,9-231,4$} & \multicolumn{2}{|c|}{$220,91 \pm 12,18^{b} 189,6-252,2$} & \multicolumn{2}{|c|}{$231,70 \pm 11,28^{\mathrm{b}} 200,4-263,0$} \\
\hline Male & \multicolumn{2}{|c|}{$299,19 \pm 47,48$} & $299,66 \pm 45,21$ & \multirow{2}{*}{\multicolumn{2}{|c|}{$\begin{array}{l}199,51 \pm 54,77 \\
202,18 \pm 40,75\end{array}$}} & \multicolumn{2}{|c|}{$233,38 \pm 28,87$} & \multicolumn{2}{|c|}{$226,13 \pm 21,41$} \\
\hline Female & \multicolumn{2}{|c|}{$319,61 \pm 48,64$} & $258,09 \pm 52,99$ & & & \multicolumn{2}{|c|}{$208,44 \pm 17,48$} & \multicolumn{2}{|c|}{$237,31 \pm 20,61$} \\
\hline $\begin{array}{l}\mathrm{CRP} \\
(\mathrm{ng} / \mathrm{ml})\end{array}$ & $64,38 \pm 5,65^{a}$ & $52,27-76,49$ & $77,88 \pm 7,67^{a} \quad 61,0-94,75$ & $41,77 \pm 4,56^{b}$ & $31,61-51,93$ & $26,57 \pm 5,45^{\mathrm{bc}}$ & $14,02-39,13$ & $9,56 \pm 2,26^{\mathrm{bc}}$ & $3,76-15,36$ \\
\hline Male & \multicolumn{2}{|c|}{$69,09 \pm 15,73$} & $80,10 \pm 22,35$ & \multicolumn{2}{|c|}{$37,67 \pm 6,53$} & \multicolumn{2}{|c|}{$28,21 \pm 9,97$} & \multicolumn{2}{|c|}{$9,54 \pm 9,19$} \\
\hline Female & \multicolumn{2}{|c|}{$58,79 \pm 21,05$} & $75,01 \pm 24,39$ & \multicolumn{2}{|c|}{$44,39 \pm 14,07$} & \multicolumn{2}{|c|}{$24,83 \pm 14,99$} & \multicolumn{2}{|c|}{$9,62 \pm 3,68$} \\
\hline
\end{tabular}

$\overline{\mathrm{a}, \mathrm{b}}$ Values with different letters are significantly different $(\mathrm{p}<0.05)$. 
Table 3. Research and results involving cardiac biomarkers ACE, ANP and CRP in rabbits

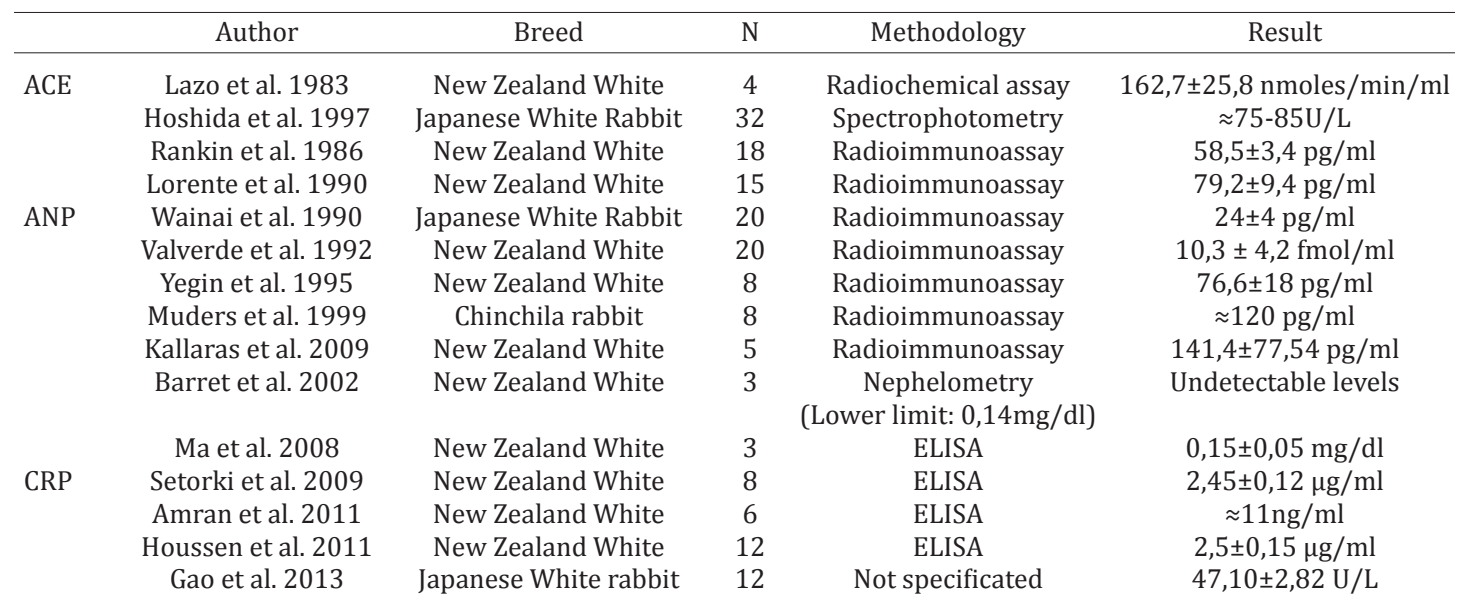

significant differences in the cardiac biomarkers between animals with different gender or body weight.

Although no statistically significant differences (ANOVA and Tukey test) were observed between genders for cardiac biomarkers, we did, in some cases, observe a variable trend between males and females. These trends are markedly conspicuous for ANP in almost all the breeds of rabbits studied (except for the Giant Flemish). On the other hand, smaller variations in CRP were observed with regards to breed differences (except for the Fuzzy Lop breed).

\section{DISCUSSION}

Although rabbits are routinely employed in cardiovascular research (Campbell et al. 1978, Rankin et al. 1986, Barret et al. 2002, Chorro et al. 2009, Dontas et al. 2011), information regarding specific biomarkers for this species is lacking in the literature.

This study is the first to characterize the serum concentration of cardiac biomarkers used for biomedical research, CRP, ANP, and ACE, in different breeds of rabbits and investigated a possible "breed effect" for variability of these cardiac markers.

Our results indicate that serum concentrations of rabbit CRP, ANP, and ACE can be measured using specifics ELISA commercial kits (Kamiya Biomedical ${ }^{\circledR}$ ). Our assays demonstrated excellent inter-assay and intra-assay CV $(<10 \%)$ and a recovery rate (approximately $100 \%)$ and are highly similar to the manufacturer-supplied dates. These values are consistent with those recommended by the International Federation of Clinical Chemistry and Laboratory Medicine (Panteghini et al. 2001).

Recently, these new cardiac biomarkers have been employed for diagnosis of heart disease, especially in experimentally-induced cardiomyopathies in animals (Muders et al. 1999). They have also proven invaluable in obtaining diagnostic, therapeutic, and prognostic information about heart failure in animals (Sisson 2004).

The results of our study demonstrate that breed variability is a limiting factor for the use of a single reference interval for cardiac markers in rabbits. This observation necessitates the need to obtain and use specific values for different breeds of rabbits.
Our results also corroborate information from previously conducted studies regarding the influence of intrinsic factors, such as breed, on the hematological and biochemical parameters in rabbits (Casey et al. 1934, 1936, Ledue \& Rifai 2003, Moesgaard et al. 2007, Carneiro et al. 2011, Özkan et al. 2012).

However, a lack of information about the influence of this breed on cardiovascular biomarkers in rabbits necessitated the use of similar studies conducted in dogs for this paper.

Ishioka et al. (2007) investigated the effect of breed on plasma leptin concentration in dogs. However, no differences between breeds were found. In another study, Höllmer et al. (2013) investigated the effect of breed on left atrial volume and phasic function in clinically healthy dogs; the results revealed a correlation between left atrial volume and function with body size.

More recently, Misbach et al. (2013) investigated the effect of breed on basal plasma concentrations of NT-proBNP in clinically-healthy adult dogs. The authors reported significant differences in plasma NT-proBNP concentration in seven different breeds. The study concluded that breed-specific reference ranges might, therefore, be necessary for optimal clinical use of natriuretic peptides as cardiac biomarkers (Misbach et al. 2013). Results of the present study corroborate the results of this study.

Although our study additionally proposed to identify the effect of gender and weight on cardiac biomarkers in a population of rabbits, our results showed no statistically significant differences. A minor tendency of variation between male and female rabbits for ANP in all breeds (except for Flemish Giant) was observed; elevated serum concentrations of ANP were observed in females, compared to males. These results were similar to those reported by Misbach et al. (2013), who demonstrated that female dogs had an elevated concentration of plasmatic NT-pro-BNP, compared to male dogs. In our study, gender-specific differences in other cardiac markers were either not observed (ACE) or were observed on a smaller scale (CRP).

Considering the lack of reference values of cardiovascular parameters in experimental rabbits (Özkan et al. 2012) 
and the prominent effect of "breed variability" on these parameters, our study provides important information for future research in the field of basic cardiovascular research involving rabbits.

Owing to this lack of information, it is difficult to compare this study with previously published studies about cardiac markers in rabbits. The lack of uniformity in methodology used for determination of biomarkers also compounds the problem.

This variability in the literature is illustrated in Table 3 , which presents the results of several studies that evaluated the serum behavior of biomarkers, including ANP, ACE, and CRP. These studies have different aims. Furthermore, the breeds of rabbits used and assay type also varied amongst these studies; only a few these used ELISA as in this study.

It is important to note that none of these studies aimed to establish a general reference for these biomarkers using established assay techniques. The data collected was compared with control groups in each investigation, some with a small number of animals. By contrast, this research evaluated the three biomarkers using the same methodology (commercial ELISA kits). Furthermore, all kits were specific for rabbits, provided by the same manufacturer and operated by a single researcher.

As observed in Table 3, the majority of authors conducted research with New Zealand White rabbits, except in a few cases (Wainai et al. 1990, Hoshida et al. 1997, Gao et al. 2013), in which the authors used the Japanese White rabbit. These results conflict with those of the current study.

Thus, laboratory techniques and racial factors need to be standardized in order to establish procedures and reference values (Vasan 2006). The present study establishes a reference interval for CRP, ANP, and ACE concentrations in five different breeds of rabbits, using the ELISA technique. The same method was applied recently (Amran et al. 2011, Gao et al. 2013) for the measurement only of CRP in rabbits, with widely variable results. However, these studies differed in the breeds and methodology used.

While conducting the literature search, we found no information on reference intervals of serum CRP, ANP, and ACE in different breed of rabbits. Hence, describing the normal values of these parameters in these breeds in this study was remarkable. Additionally, as shown in Table 2, significant statistical differences in the parameters CRP, ANP, and ACE were found between these breeds.

This study presents several limitations. First, inclusion and exclusion criteria of animals were based on the non-existence of cardiopathies by general clinical state of the animal and the non-existence of cardiac murmurs or arrhythmias perceptible by auscultation; not having conducted complementary exams, such as chest X-ray or echocardiography. Second, it is known that the clinical use of ANP is lower than the NT-proBNP, meaning that ANP does not represent the biomarker of choice for laboratory determination of early congestive processes. However, the choice for the determination of this biomarker is included in the scope of our research group, which is developing new research on several other biomarkers, such as NT-pro-BNP. In all cases, our research employed the ELISA method because it is quantitative, specific, more practical, and safer than other techniques, such as radioimmunoassay.

\section{CONCLUSIONS}

This study demonstrates that serum ANP, ACE, and CRP concentration is characterized by a high inter-individual and inter-breed variability in healthy rabbits. We also demonstrated that no influence of gender was found, although ANP females had slightly higher concentrations than males. The clinical relevance of gender differences requires further investigation.

It is believed that this technique and information about the different serum concentrations of these biomarkers in each race can assist in future clinical cardiology and diagnosis of heart diseases.

On other hand, prospective studies, including a larger sample size and other breeds, are, therefore, needed to better understand ANP, ACE, and CRP physiology in rabbits.

Acknowledgements.- This study was supported by the Veterinary Hospital of the Darcy Ribeiro, North Fluminense State University, Brazil. The authors would like to thank the Hatchery of Coelhos Lagoa Funda for their contributions and Alexandre Pio Viana, PhD, and statistical professor, Darcy Ribeiro, North Fluminense State University, Brazil University, for statistical analysis for this research.

Conflict of interest statement.- The authors have no competing interests.

\section{REFERENCES}

Amran A.A., Zakaria Z., Othman F., Das S., Al-Mekhlafi H.M. \& Nordin N.M.M. 2011. Changes in the vascular cell adhesion molecule-1, intercellular adhesion molecule- 1 and C-reactive protein following administration of aqueous extract of piper sarmentosum on experimental rabbits fed with cholesterol diet. Lipids Health Dis. 10:1-8.

Barrett T.D., Hennan J.K., Marks R.M. \& Lucchesi B.R. 2002. C-Reactive-Protein-Associated Increase in Myocardial Infarct Size After Ischemia/ Reperfusion. J. Pharmacol. Exp. Ther. 303:1007-1013.

Campbell W.G., Donohue J.A. \& Duket L.H. 1978. The Capacity to Develop Hypertension-Associated Arterial Disease. Am. J. Pathol. 93:383-404.

Casey A.E., Rosahn P.D., Hu C.K. \& Pearce L. 1934. Hereditary variations in the blood cytology of normal rabbits. Science 79:189-190.

Casey A.E., Rosahn P.D., Hu C.K. \& Pearce L. 1936. The hemocytological constitution of adult male rabbits from fifteen standard breeds. J. Exp. Med. 64:453-469.

Carneiro M., Afonso S., Geraldes A., Garreau H., Bolet G., Boucher S., Tircazes A., Queney G., Nachman M.W. \& Ferrand N. 2011. The Genetic Structure of Domestic Rabbits. Mol. Biol. Evol. 28:1801-1816.

Chorro F.J., Belenguer L.S. \& Merino V.L. 2009. Medicina cardiovascular traslacional. Modelos animales de enfermidad cardiovascular. Revta Esp. Cardiol. 62:69-84.

CLSI 2008. Defining, Establishing, and Verifying Reference Intervals in the Clinical Laboratory: approved guideline. 3rd ed. CLSI document C28-A3. Clinical and Laboratory Standards Institute, Wayne, PA.

Dontas I.A., Marinou K.A., Iliopoulos D., Tsantila N., Agrogiannis G., Papalois A. \& Karatzas T. 2011. Changes of blood biochemistry in the rabbit animal model in atherosclerosis research; a time or stress-effect. Lipids Health Dis. 10:139-144.

Ecker C. \& Cichna-Markl M. 2012. Development and validation of a sandwich ELISA for the determination of potentially allergenic lupine in food. Food Chem. 130:759-766.

Flecknell P.A. 1993. Anaesthesia of animals for biomedical research. Braz. J. Anaesthesiol. 71:885-894. 
Fonseca N.M., Goldenberg S., Gomes P.O. \& Lima C.A. 1996. Anestesia em coelhos. Acta Cir. Bras. 11:82-104.

Gao X.Q., Li H.W., Ling X., Qiu Y.H., Gao Y.G. \& Zhang Y. 2013. Effect of rosiglitazone on rabbit model of myocardial ischemia-reperfusion injury. Asian Pac. J. Trop. Med. 6:228-231.

Höllmer M., Willesen J.L., Tolver A. \& Koch J. 2013. Left atrial volume and phasic function in clinically healthy dogs of 12 different breeds. Vet. J. 197:639-645.

Hoshida S., Nishida M., Yamashita N., Igarashi J., Aoki K., Hori M., Kuzuya T. \& Tada M. 1997. Vascular angiotensin-converting enzyme activity in cholesterol-fed rabbits: effects of enalapril. Atherosclerosis 130:53-59.

Houssen M.E., Haron M.M., Metwally S.S. \& Ibrahim T.M. 2011. Effects of immunomodulatory drugs on plasma inflammatory markers in a rabbit model of atherosclerosis. J. Physiol. Biochem. 67:115-120.

Ishioka K., Hosoya K., Kitagawa H., Shibata H., Honjoh T., Kimura K. \& Saito M. 2007. Plasma leptin concentration in dogs: Effects of body condition score, age, gender and breeds. Res. Vet. Sci. 8:211-215.

Kallaras K., Babas G., Stergiou-Michailidou V., Karamouzis M. \& Zaraboukas T. 2009. Atrial natriuretic peptide decreases aorta stiffness in cholesterol-fed anesthetized rabbits. Pharm. Res. 60:324-331.

Lazo J.S., Catravas J.D., Dobuler K.J. \& Gillis C.N. 1983. Prolonged reduction in serum angiotensin converting enzyme activity after treatment of rabbits with bleomycin. Toxicol. Appl. Pharm. 69:276-282.

Ledue T.B. \& Rifai N. 2003. Preanalytic and analytic sources of variations in c-reactive protein measurement: implications for cardiovascular disease risk assessment. Clin. Chem. 49:1258-1271.

Lorente J.A., Villanueva E., Hernaández-Cueto C. \& Luna J.D. 1990. Plasmatic levels of atrial natriuretic peptide (ANP) in drowning: a pilot study. Forensic Sci. Int. 44:69-75.

Lord B., Boswood A. \& Petrie A. 2010. Electrocardiography of the normal domestic pet rabbit. Vet. Rec. 167:961-965.

Ma H., Chen G., Young J. \& Cherng S. 2008. C-reactive protein (CRP) rise is associated with the development of acute events in a model of plaque rupture and thrombosis. Life Sci. J. 5:21-24.

Misbach C., Chetboul V., Concordet D., Gruet P., Speranza C., Hoffmann A.C., Rocha A., Balouka D., Petit A.M.P., Trehiou-Sechi E., Pouchelon J.L. \& Lefebvre H.P. 2013. Basal plasma concentrations of N-terminal pro-B-type natriuretic peptide in clinically healthy adult small size dogs: effect of body weight, age, gender and breed, and reference intervals. Res. Vet. Sci. 95:879-885.

Moesgaard S.G., Holte A.V., Mogensen T., Molbak J., Kristensen A.T., Jensen A.L., Teerlink T., Reynolds A.J. \& Olsen L.H. 2007. Effects of breed, gender, exercise and white-coat effect on markers of endothelial function in dogs. Res. Vet. Sci. 82:409-415.

Muders F., Friedrich E., Luchner A., Pfeifer M., Ickenstein G., Hamelbeck
B., Riegger G.A.J. \& Elsner D. 1999. hemodynamic changes and neurohumoral regulation during development of congestive heart failure in a model of epinephrine-induced cardiomyopathy in conscious rabbits. J. Cardiac Failure 5:109-116.

Oyama M.A. \& Solter P.F. 2004. Validation of an immunoassay for measurement of canine cardiac troponin-I. J. Vet. Cardiol. 6:17-24.

Özkan C., Kaya A. \& Akgül Y. 2012. Normal values of haematological and some biochemical parameters in serum and urine of New Zealand White rabbits. World Rabbit Sci. 20:253-259.

Pairaut R. 2009. Cardiovascular physiology and diseases of the rabbit. Vet. Clin. North Am., Exot. Anim. Pract. 12:135-144.

Panteghini M., Gerhardt W., Apple F.S., Dati F., Ravkilde J. \& Wu A.H. 2001. Quality specifications for cardiac troponin assays. Clin. Chem. Lab. Med. 39:175-179.

Petronianu A. 1996. Aspectos éticos na pesquisa em animais. Acta Cir. Bras. 11:157-164.

Pogwizd S.M. \& Bers D.M. 2008. Rabbit models of heart disease: drug disco. Today Dis. Models 5:185-193.

Rankin A.J., Courney C.A., Wilson N. \& Ledsome J.R. 1986. Tachycardia releases atrial natriuretic peptide in the anesthetized rabbit. Life Sci. 38:1951-1957.

Setorki M., Asgary S., Eidi A., Rohani A.H. \& Esmaeil N. 2009. Effects of apple juice on risk factors of lipid profile, inflammation and coagulation, endothelial markers and atherosclerotic lesions in high cholesterolemic rabbits. Lipids Health Dis. 8:1-9.

Sisson D. 2004. Neuroendocrine evaluation of cardiac disease. Vet. Clin. North Am., Small Anim. Pract. 34:1105-1126.

Szabuniewicz M., Hightower D. \& Kyzar J.R. 1971. The electrocardiogram, vectorcardiogram and spatiocardiogram in the rabbit. Can. J. Comp. Med. 35:107-114.

Vasan R.S. 2006. Biomarkers of cardiovascular disease: molecular basis and practical considerations. Circulation 113:2335-2362.

Valverde J., Martinez-Rodenas F., Pereira J.A., Carulla X., Jimenez W., Gubern J.M. \& Sitges-Serra A. 1992. Rapid Increase in Plasma Levels of Atrial Natriuretic Peptide After Common Bile Duct Ligation in the Rabbit. Ann. Surg. 216:554-559.

Wainai Y., Kusuhara M., Yamada T., Yoshikawa T., Suzuki M., Hori S., Handa S., Yoshinaga K. \& Yamaguchi K. 1990. Atrial natriuretic peptide secretion in rabbits with aortic regurgitation. Res. Exp. Med. 190:13-18.

Yu L., Pragay D.A., Chang D. \& Wicher K. 1979. Parameters of normal rabbit serum. Clin. Biochem. 12:83-87.

Yegin E., Akcay F., Yigitoglu M.R., Celik I., Suzek H. \& Odabasioglu F. 1995. plasma atrial natriuretic peptide levels in rabbits with alloxan monohydrate induced diabetes mellitus. Jap. Heart J. 36:789-795. 